\title{
Soil quality assessment in difference vegetation structures of Surajpur lake: An urban wetland of Upper Gangetic plain, Northern India
}

\author{
Nasim Ahmad Ansari ${ }^{1^{*}}$ and Jeet Ram $^{2}$ \\ ${ }^{1}$ Wildlife Institute of India, Post Box \# 18 Chandrabani, Dehradun- 248008 (Uttarakhand), INDIA \\ ${ }^{2}$ Department of Forestry \& Environmental Science, Kumaun University, Nainital-263129 (Uttarakhand), INDIA \\ *Corresponding author. E-mail: dr.ansari.nasim@gmail.com
}

Received: March 6, 2016; Revised received: September 6, 2016; Accepted: December 7, 2012

\begin{abstract}
Surajpur Lake is the prominent wetland site in National Capital Region, India known for its rich avifaunal and other aquatic biodiversity. Present study was carried out to assess the soil quality in different vegetation structures in Surajpur wetland from March 2010 to February 2013. Soil Sampling was conducted in five different vegetation habitats in the study area by applying standard sampling protocols. A total of 9 Physical and 16 chemical parameters were selected for analysis. The overall means of physical parameters of soil sample includes soil moisture content $11.17 \pm 3.03 \%$, bulk density $1.19 \pm 0.01 \mathrm{gm} / \mathrm{ml}$, porosity $35.00 \pm 5.10 \%$, water holding capacity $35.00 \pm$ $3.86 \%$, soil organic carbon $0.09 \pm 0.05 \%$, electrical conductivity $276.42 \pm 112.83 \mathrm{ds} / \mathrm{m}$, pH value $9.98 \pm 0.42$ was recorded. The means of chemical parameters of soil sample includes total Kjeldahl nitrogen $286.76 \pm 42.41 \mathrm{mg} / \mathrm{kg}$, available phosphorus $338.50 \pm 32.75 \mathrm{mg} / \mathrm{kg}$, potassium $2.85 \pm 0.39 \mathrm{mg} / \mathrm{kg}$, calcium level $10.86 \pm 673 \mathrm{mg} / \mathrm{kg}$, magnesium $10.56 \pm 4.43 \mathrm{mg} / \mathrm{kg}$, iron $14.90 \pm 1.99 \mathrm{mg} / \mathrm{kg}$, manganese $289.13 \pm 42.89 \mathrm{mg} / \mathrm{kg}$, zinc $4.20 \pm 0.45 \mathrm{mg} / \mathrm{kg}$, chloride $223.73 \pm 62.64 \mathrm{mg} / \mathrm{kg}$, sulphate $150.21 \pm 27.99 \mathrm{mg} / \mathrm{kg}$ and silica oxide $7.97 \pm 1.45 \mathrm{mg} / \mathrm{kg}$. Boron, Copper and Molybdenum nutrients recorded less than one $\mathrm{mg} / \mathrm{kg}$ in the soil sample. The viable count of bacteria recorded an overall mean of $16,56,000.00 \pm 11,06,157.31 \mathrm{cfu} / \mathrm{g}$. The results indicated that the essential mineral nutrients are widely distributed in the soil and are pollution free and also no any organic waste is coming to the site. Soil is good enough to support rich biodiversity to form a complete food web in the Surajpur wetland ecosystem.
\end{abstract}

Keywords: Habitats, Soil, Surajpur wetland, Vegetation

\section{INTRODUCTION}

Wetlands are referred as "biological supermarkets" because they support all life forms through extensive food webs and biodiversity (Mitsch and Gosselink, 1989). Through the ages, urban wetlands have been the lifeline of most cities in India. They provide multiple values for suburban and city dwellers (Castelle et al., 1994). The capacity of a functional urban wetland in flood control, aquatic life support and as pollution sink implies a greater degree of protection (Ramachandran, 2001). The essential minerals and organic matter present in the wetland surface are in the form of soil and soil quality is "the capacity of soil to function within ecosystem boundaries to sustain biological productivity, maintain environmental quality and promote plant and animal health" (Doran and Parkin, 1994). Soils are the unconsolidated mineral or organic material on the immediate surface of the earth that serves as a natural medium for the growth of land plants. Healthy soils are crucial for ensuring the continued growth of natural and managed vegetation, providing ecosystem services such as climate regulation and oxygen production. Soil quality assessments provide a better understanding and awareness that soil resources are truly living bodies with biological, chemical, and physical properties and processes performing essential ecosystem services (Karthick and Ramachandran, 2006). The future of our food security depends upon the attention we pay to soil health care and the conservation and efficient use of water (Swaminathan, 2005). Soil quality assessment plays a very important role in diagnosing the physical, chemical and biological properties of the soils by providing the conditions of available nutrients which indicates the fertility and productivity of the soils (Lungmuana and Colney, 2011). Soil sampling and testing provides an estimate of the capacity of the soil to supply adequate nutrients to meet the needs of growing vegetation. Vegetation directly influences climate in several ways including through albedo and surface roughness and indirectly, vegetation contributes organic matter to the soil which affects albedo, adds insulation and increases water holding capacity and infiltration (Balling et al., 1998). Soil characteristics are necessary to gain a comprehensive knowledge about the functioning of the wetland ecosystem and association of vegetation structure.

The Gangetic Plains in India form an important biogeographic zone characterized by fine alluvium and clay rich swamps, fertile soil and high water retention 
capacity. Around 400 species of angiosperms have been recorded from this bio geographic zone (Manral et al., 2013). The Upper Gangetic Plains (UGP) are scattered with several natural fresh water wetlands has the highest human density in India of 800-1200 people per $\mathrm{km}^{2}$, which has thus resulted in high human impact on natural ecosystems (Manral et al., 2013). Surajpur Lake is one such wetland in urban surrounding in UGP.

Soil quality assessment started in late 1940s in USA and it began in India in 1955-56. Soil testing is well recognized as a sound scientific tool to assess inherent power of soil to supply plant nutrients. Numerous studies are available on various aspects of soil assessment such as Bhattacharyya et al. (2013) reviewed the historical perspective, classification and recent advances of Soils of India; Ray et al. (2014) reported soil and land quality indicators of the Indo-Gangetic Plains of India; Singh et al. (2004) studied the soils of Uttar Pradesh for optimising land use; Yadav et al. (2013) investigated heavy metal status in soil and vegetables grown in urban area of Allahabad, Uttar Pradesh; Gowd et al., 2010 made an assessment of heavy metal contamination in soils at Jajmau (Kanpur) and Unnao industrial areas of the Ganga Plain, Uttar Pradesh; Yadav and Shukla (2015) assessed Heavy metal accumulation in wastewater flooded soil of Allahabad, Uttar Pradesh; Tiwari et al. (2014) made an appraisal of available sulphur and micronutrient status in southwest plain zone soils of Agra, Uttar Pradesh. However, very few studies have been available to assess the soil and vegetation structure such as Pilania and Panchal (2014) assessed the soil-plant relationship in Little Rann of Kutch, Gujarat India; Raina and Gupta (2009) assessed the soil and vegetation studies in relation to parent material of Garhwal Himalayas, India and there is no such study available on soils and vegetation structure in UGP. Hence, the present study, has been done to study the physicochemical properties of soil in different vegetation structures of Surajpur wetland to arrive at certain conclusions on the relationship of soil and vegetation aspects of the area and to suggest ways and means for its conservation.

\section{MATERIALS AND METHODS}

Study area: The present study was conducted in $\mathrm{Su}$ rajpur wetland $\left(28^{\circ} 31.425^{\prime} \mathrm{N} ; 77^{\circ} 29.714^{\prime} \mathrm{E}\right)$, which is an urban wetland located in district Gautam Budh Nagar, Uttar Pradesh under Delhi- National Capital Region (NCR) India (Fig. 1) and it is only 3 kilometres from Greater Noida City, which is one of the best planned cities and is the largest industrial townships of Asia (Joshi, 2009). The study area falls in the Upper Gangetic plain bio geographic Zone (Rodgers et al., 2002) at an elevation of $184.7 \mathrm{~m}$ above MSL. The area is a reserve forest (viz. Khodna Khurd Reserve Forest and Gulistanpur Reserve Forest) and spreads over 308 hectare $\left(3.08 \mathrm{Km}^{2}\right)$ including 60 hectares $\left(0.60 \mathrm{Km}^{2}\right)$ of natural perennial wetland (Bura et al., 2013). The area is mainly rain-fed and other sources for water recharge are Hawaliya drain, which is attached to Hindon River and Tilapta irrigation canal. Based on the normal rainfall pattern and other climate factors, the general climate is tropical monsoon type with three distinct ecological seasons viz., Summer (March, April, May and June), Monsoon (July, August, September and October) and winter (November, December, January and February). The study area receives most of its precipitation during monsoon, which sets usually between June ends to September every year ranging from $400-500 \mathrm{~mm}$ and normally the rain depends on north-west monsoon. The mean monthly maximum and minimum temperature ranges between $17.89{ }^{\circ} \mathrm{C}$ and $41.69{ }^{\circ} \mathrm{C}, 6.86{ }^{\circ} \mathrm{C}$ and $30.35^{\circ} \mathrm{C}$ respectively and highest temperature was observed during June and the lowest during January.. The terrain of the area is almost plain, although the area divides into flat terrestrial form and deep wetland area. There is a gentle slope from west to east in the wetland area. The terrestrial tract is almost plain with interspersed shallow ditches. The rain water flows through these ditches and collects into the wetland area. The soil is alluvial type which has mainly resulted from the deposition of fine sand and clay from the River Yamuna and its tributaries. The wetland area has fine grained soil called lacustrine soil. The Gulistanpur reserve forest area $\left(1.22 \mathrm{Km}^{2}\right)$ is in general 'Usar' land due to saline soil with contents of alkaline metals and soluble salts.

\section{Methodology}

Habitat characterisation: Different vegetation structures of Surajpur wetland categorised into four major habitats on the basis of vegetation and soil type, woodland, grassland, wetland and marshland habitats (Fig. 2.). Soil quality assessment was performed in woodland and grassland habitats. These major habitats further divided into microhabitats; woodland includes Phoenix sylvestris, Terminalia arjuna, Syzigium cumini and Prosopis juliflora; grassland are dominant with Sachharum sp., Vetiveria zizanioides and Desmostachya bipinnata species; whereas wetland includes clear water with submerged aquatic vegetation of Certaophyllum demersum, Hydrilla verticillata, Vallisneria spiralis; emergent aquatic vegetation of Eichhornea crassipes, Alternanthera philoxeroides, Ipomoea sp., Typha angustata; and marshland with Phoenix sylvestris, Terminalia arjuna, Syzygium cumini vegetation (Fig. 3). The mosaics of habitat formed the different vegetation structures serve as a good habitat for various types of biodiversity exists in the study area.

Soil quality assessment: The process of soil testing involved four steps, sampling, analysis, interpretation and recommendations (Kissel and Sonon, 2008). Composite soil samples were collected from the study area in December 2012 from 5 different locations of woodland (i.e. Terminalia arjuna-TA, Syzigium cumini- SC, 
Phoenix sylvestris- PS, Prosopis juliflora- PJ) and grassland (GR) habitats. One kilogram sample was collected from 5 centimeters depth using an auger and core after removing the top soil humus from each location, packed in polythene bag and brought to the laboratory for analysis. A total of 25 parameters selected for analysis including visual, physical and chemical properties of soil by using standard methods of analysis of soil samples. Soil Texture, Water Holding Capacity, Soil Porosity, Soil Colour, Soil Bulk Density, Chloride (Cl) and Phosphorus (P) were analysed following Gupta, (2004); Total Kjeldahl Nitrogen (TKN), Sulphate (SO4), Electrical Conductivity (EC) and Moisture content were analysed following International Standard Organisation methods (ISO, 2001); heavy metals like Silica $\left(\mathrm{SiO}_{2}\right)$, Copper $(\mathrm{Cu})$, Zinc $(\mathrm{Zn})$, Manganese (Mn), Molybdenum (Mo), Boron (B), Sodium (Na), Potassium (K), Calcium (Ca), Magnesium (Mg), Iron (Fe) were analysed following USEPA 3050B (USEPA, 1996); and Total Plate Count (TPC) for microbial analysis of soil samples were analysed following APHA, (2001 and 2006).

\section{RESULTS AND DISCUSSION}

The results obtained for 25 physicochemical parameters of soil of Surajpur wetland represent spatial variation across the five different locations (habitats) in the study area. The results of analytical, visual \& physical parameters are depicted in Table 1 and results of chemical parameters are given in Table 2. The soil colour in the study area varies from yellowish (TA, and PJ) to brownish (GR) and greyish (SC) with Silty clay loam soil texture. Yellowish, greyish and brownish colours of soils signify the intermediate state of aeration, low water holding capacity.

Soil moisture content recorded an overall mean of $11.17 \pm 3.03 \%$, while the value ranges between 7.42
$\%$ (GR) and $14.96 \%$ (SC) and these are under the permissible limits (10-15\%). The bulk density of soil depends upon the volume of soil (Srivastava and Yadav, 2014). Bulk density represents almost similar in all the locations and an overall mean of $1.19 \pm 0.01 \mathrm{gm} / \mathrm{ml}$ were recorded. TA and $\mathrm{PJ}$ recorded minimum bulk density values $1.18 \mathrm{gm} / \mathrm{cm}^{3}$ and $\mathrm{SC}$ recorded maximum bulk density values $1.20 \mathrm{gm} / \mathrm{cm}^{3}$ and these values are under the permissible limits (maximum limit is $1.55 \mathrm{gm} / \mathrm{cm}^{3}$ ). Srivastava and Yadav (2014) reported bulk density slightly lower than present study 0.28 to $0.42 \mathrm{gm} / \mathrm{cm}^{3}$. Bulk density is an indicator of soil porosity and soil compaction. Porosity is the aeration property of soil and is recorded maximum in PJ (40\%) and minimum in PS $(27 \%)$ with an overall mean of $35.00 \pm 5.10 \%$. Lower the bulk density higher the porosity of soil which helps the nutrients to move smoothly. Porosity correlates with water holding capacity. Water holding capacity of the soil is the property of soil to trap the moisture content with soil particles and the values recorded maximum in GR (42.20\%) and minimum in SC (31.00\%) with an overall mean of $35.00 \pm 3.86 \%$. Srivastava and Yadav, (2014) reported similar water holding capacity of $(25 \%-50 \%)$ in soils of Bundelkhand, India.

The soil organic carbon is the proportion of carbon content in the total organic matter of the soil. It is one of the important soil properties and one of the chief elements of organic matter. Organic carbon is necessary for all growth about $80 \%$ of bacterial drymass. The Organic carbon value ranged between $0.03 \%(\mathrm{PJ})$ and $0.17 \%$ (SC) with an overall mean of $0.09 \pm 0.05$ $\%$ in Surajpur wetland. Here SC recorded maximum soil organic carbon content because of proximity to the wetland area, soils were wet all the time, resulting high carbon content in the soil, whereas in PJ woodland remains dry round the year except monsoons resulting

Table 1. Various physical properties of soil samples in Surajpur wetland.

\begin{tabular}{|c|c|c|c|c|c|c|c|}
\hline \multirow{2}{*}{ S. No. } & \multirow{2}{*}{ Physical parameters } & \multicolumn{5}{|c|}{ Habitats* } & \multirow{2}{*}{ Mean $( \pm$ SD) } \\
\hline & & TA & SC & PS & PJ & GR & \\
\hline 1. & Colour & Yellowish & Greyish & Yellowish & Yellowish & Brown & - \\
\hline 2. & Soil texture & $\begin{array}{l}\text { Silty Clay } \\
\text { Loam }\end{array}$ & $\begin{array}{l}\text { Silty Clay } \\
\text { Loam }\end{array}$ & $\begin{array}{l}\text { Silty Clay } \\
\text { Loam }\end{array}$ & $\begin{array}{l}\text { Silty Clay } \\
\text { Loam }\end{array}$ & $\begin{array}{l}\text { Silty Clay } \\
\text { Loam }\end{array}$ & - \\
\hline 3. & Soil moisture (\%) & 10.89 & 14.96 & 14.24 & 8.34 & 7.42 & $\begin{array}{l}11.17 \\
( \pm 3.03)\end{array}$ \\
\hline 4. & $\begin{array}{l}\text { Bulk density }(\mathrm{gm} / \\
\left.\mathrm{cm}^{3}\right)\end{array}$ & 1.18 & 1.20 & 1.19 & 1.18 & 1.19 & $1.19( \pm 0.01)$ \\
\hline 5. & Porosity (\%) & 31.00 & 39.00 & 27.00 & 40.00 & 38.00 & $\begin{array}{l}35.00 \\
( \pm 5.10)\end{array}$ \\
\hline 6. & $\begin{array}{l}\text { Water holding capaci- } \\
\text { ty }(\%)\end{array}$ & 35.30 & 31.00 & 32.80 & 33.70 & 42.20 & $\begin{array}{l}35.00 \\
( \pm 3.86)\end{array}$ \\
\hline 7. & $\begin{array}{l}\text { Electrical conductivity } \\
(\mathrm{ds} / \mathrm{m})\end{array}$ & 271.00 & 115.10 & 459.00 & 314.00 & 223.00 & $\begin{array}{l}276.42 \\
( \pm 112.83)\end{array}$ \\
\hline 8. & Soil pH & 9.70 & 9.30 & 10.30 & 10.20 & 10.40 & $9.98( \pm 0.42)$ \\
\hline 9. & Organic Carbon (\%) & 0.09 & 0.17 & 0.07 & 0.03 & 0.09 & $0.09( \pm 0.05)$ \\
\hline
\end{tabular}

*Habitats: TA= Terminalia arjuna, $\mathrm{SC}=$ Syzygium cumini, $\mathrm{PS}=$ Phoenix sylvestris, $\mathrm{PJ}=$ Prosopis juliflora, $\mathrm{GR}=\mathrm{Grassland}$ 
Table 2. Various chemical properties of soil samples in Surajpur wetland.

\begin{tabular}{|c|c|c|c|c|c|c|c|}
\hline \multirow{2}{*}{$\begin{array}{l}\text { S. } \\
\text { No. }\end{array}$} & \multirow{2}{*}{ Chemical parameters } & \multicolumn{5}{|c|}{ Habitats } & \multirow{2}{*}{ Mean ( \pm SD) } \\
\hline & & TA & SC & PS & PJ & GR & \\
\hline 1. & $\begin{array}{l}\text { Total Kjeldahা Nitrogen } \\
(\mathrm{mg} / \mathrm{kg})\end{array}$ & 343.15 & 327.88 & 253.08 & 233.05 & 276.66 & $286.76( \pm 42.41)$ \\
\hline 2. & Phosphorus (mg/kg) & 374.24 & 297.94 & 342.55 & 373.69 & 304.08 & $338.50( \pm 32.75)$ \\
\hline 3. & Potassium (mg/kg) & 2.75 & 3.00 & 3.16 & 3.19 & 2.14 & $2.85( \pm 0.39)$ \\
\hline 4. & Calcium (mg/kg) & 9.89 & 16.08 & 20.75 & 3.91 & 3.65 & $10.86( \pm 6.73)$ \\
\hline 5. & Magnesium (mg/kg) & 11.82 & 12.11 & 17.45 & 5.66 & 5.78 & $10.56( \pm 4.43)$ \\
\hline 6. & Iron $(\mathrm{mg} / \mathrm{kg})$ & 13.31 & 12.53 & 16.07 & 18.08 & 14.53 & $14.90( \pm 1.99)$ \\
\hline 7. & Manganese (mg/kg) & 256.99 & 263.04 & 281.38 & 270.91 & 373.34 & $289.13( \pm 42.89)$ \\
\hline 8. & Zinc (mg/kg) & 4.29 & 4.87 & 3.74 & 4.43 & 3.65 & $4.20( \pm 0.45)$ \\
\hline 9. & Chloride (mg/kg) & 249.20 & 125.09 & 308.71 & 186.62 & 249.04 & $223.73( \pm 62.64)$ \\
\hline 10. & Sulphate (mg/kg) & 165.86 & 119.03 & 121.70 & 150.80 & 193.65 & $150.21( \pm 27.99)$ \\
\hline 11. & Silica Oxide $(\mathrm{mg} / \mathrm{kg})$ & 6.4 & 6.89 & 9.12 & 10.21 & 7.23 & $7.97( \pm 1.45)$ \\
\hline 12. & Boron $(\mathrm{mg} / \mathrm{kg})$ & $<1$ & $<1$ & $<1$ & $<1$ & $<1$ & - \\
\hline 13. & Copper $(\mathrm{mg} / \mathrm{kg})$ & $<1$ & $<1$ & $<1$ & $<1$ & $<1$ & - \\
\hline 14. & Molybdenum (mg/kg) & $<1$ & $<1$ & $<1$ & $<1$ & $<1$ & - \\
\hline 15. & Sodium $(\mathrm{mg} / \mathrm{kg})$ & $<1$ & $<1$ & 1.20 & 3.56 & $<1$ & $2.38( \pm 1.18)$ \\
\hline 16. & Total plate Count (cfu/g) & 680000.00 & 740000.00 & 860000.00 & 2800000.00 & 3200000.00 & $\begin{array}{l}1656000.00 \\
( \pm 1106157.31)\end{array}$ \\
\hline
\end{tabular}

*Habitats: $\mathrm{TA}=$ Terminalia arjuna, $\mathrm{SC}=$ Syzygium cumini, $\mathrm{PS}=$ Phoenix sylvestris, $\mathrm{PJ}=$ Prosopis juliflora, $\mathrm{GR}=\mathrm{Grassland}$

least carbon content in the soil. Dry soils have lesser carbon fixation rates in comparison to wet soil (Bahuguna et al., 2012). Organic carbon is in agreement with the findings of several works (Morisada et al., 2004 and Chaudhary et al., 2013).

Soil Salinity is the concentration of salt in soil measured by EC (Whitney and Means, 1897). EC measured an overall mean of $276.42 \pm 112.83 \mathrm{ds} / \mathrm{m}$ and the value ranged between $115.10 \mathrm{ds} / \mathrm{m}$ (SC) and $459.00 \mathrm{ds} / \mathrm{m}$ (PS). EC values recorded slightly higher, due to high

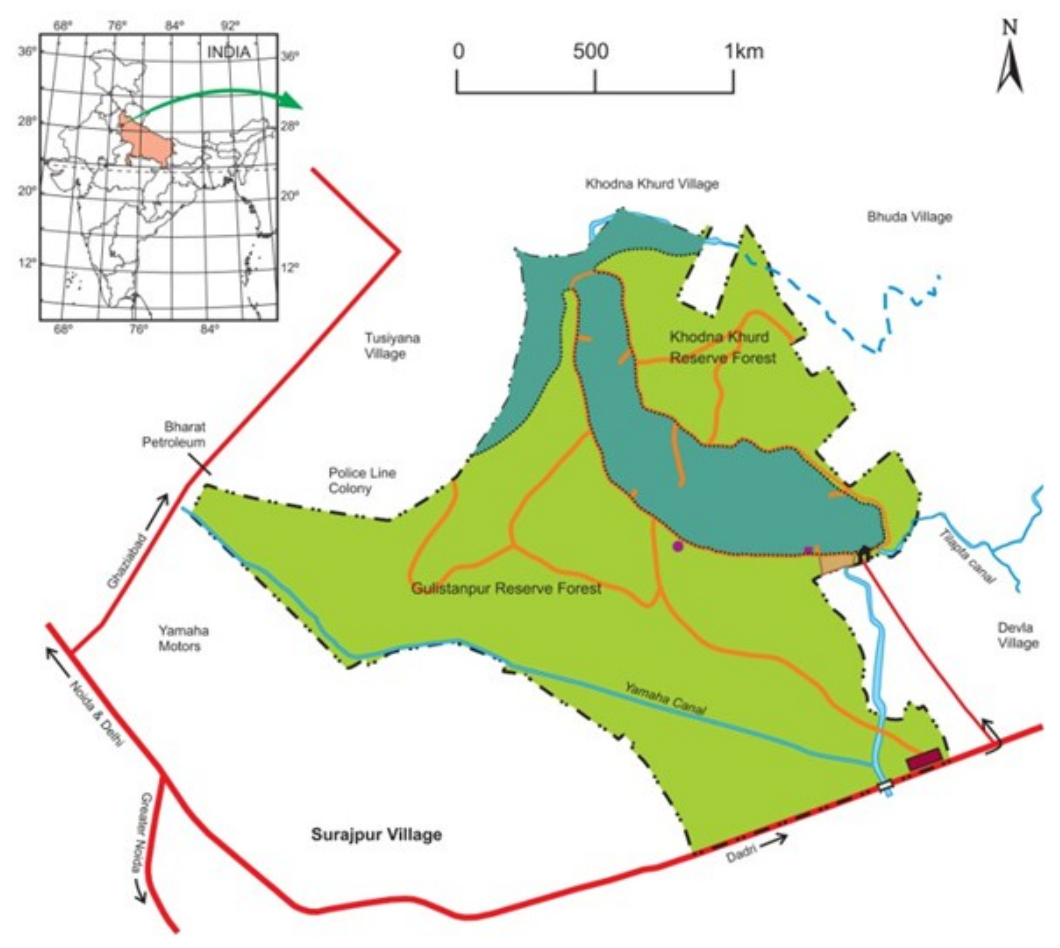

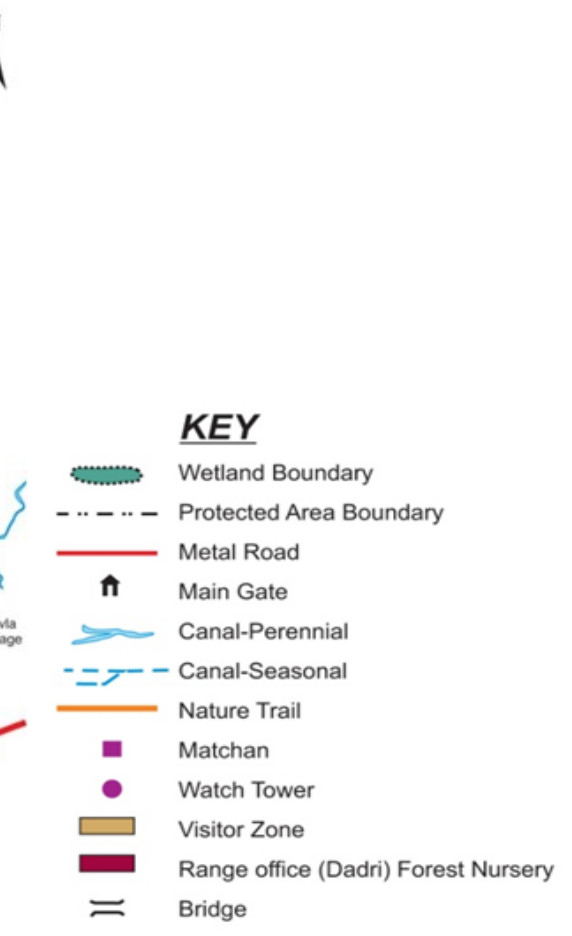

salt concentration in soils of the study area and resulting high $\mathrm{pH}$ value (Shrivastava, 1996 and Mendhe, 1997). The $\mathrm{pH}$ value ranges from 9.30 (SC) to 10.40 (GR) with an overall mean of $9.98 \pm 0.42$, which is slightly basic in nature due to high Hydrogen concentration in the different habitats of the study area. High alkalinity of soils recorded due to low precipitation, dry, arid soils which leading to weathering of calcium carbonate rich parent material. Mahajan and Billore, (2014) also recorded slightly higher EC and $\mathrm{pH}$ in

Fig. 1. Map of the Surajpur wetland. 


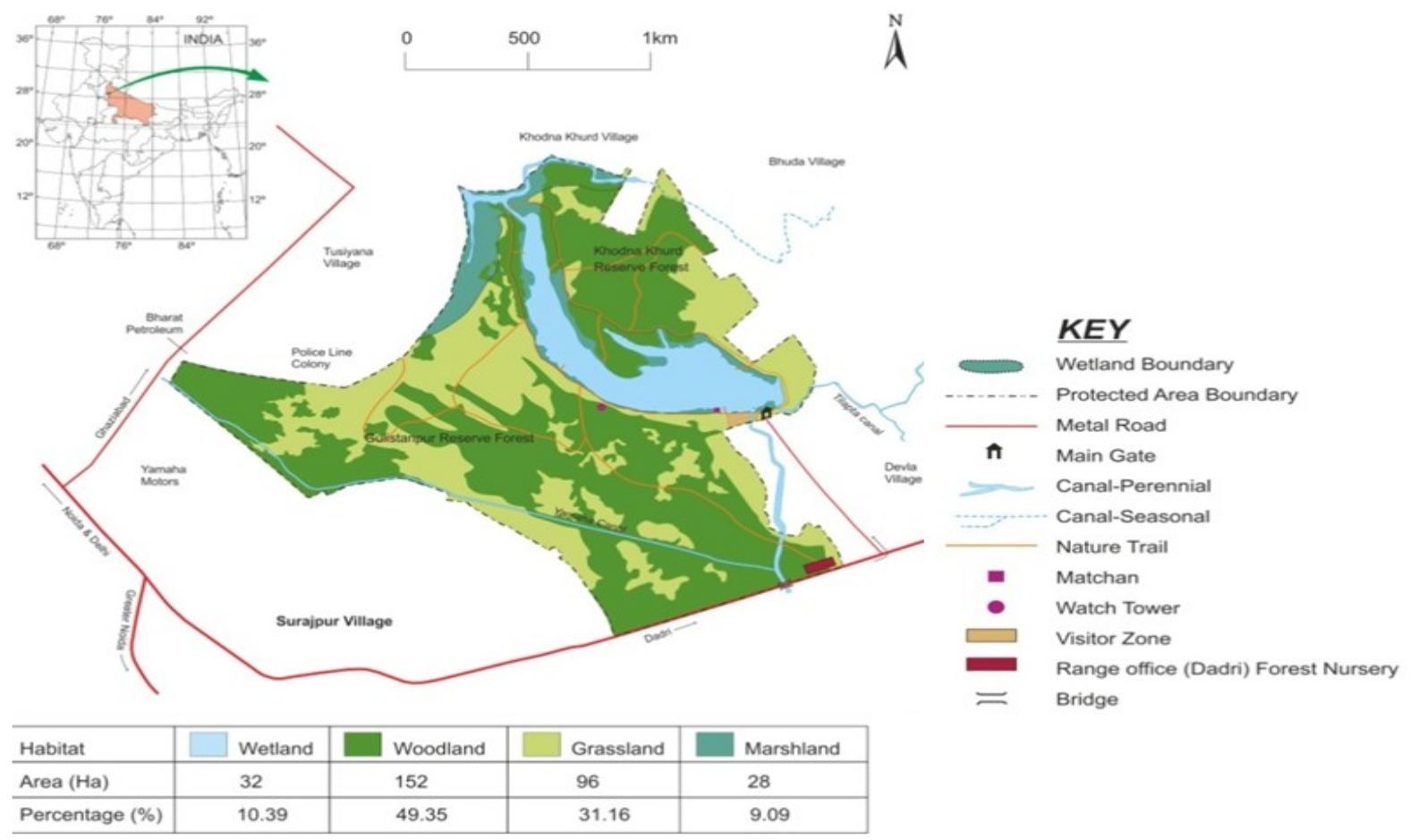

Fig. 2. Map showing major habitats of Surajpur wetland.

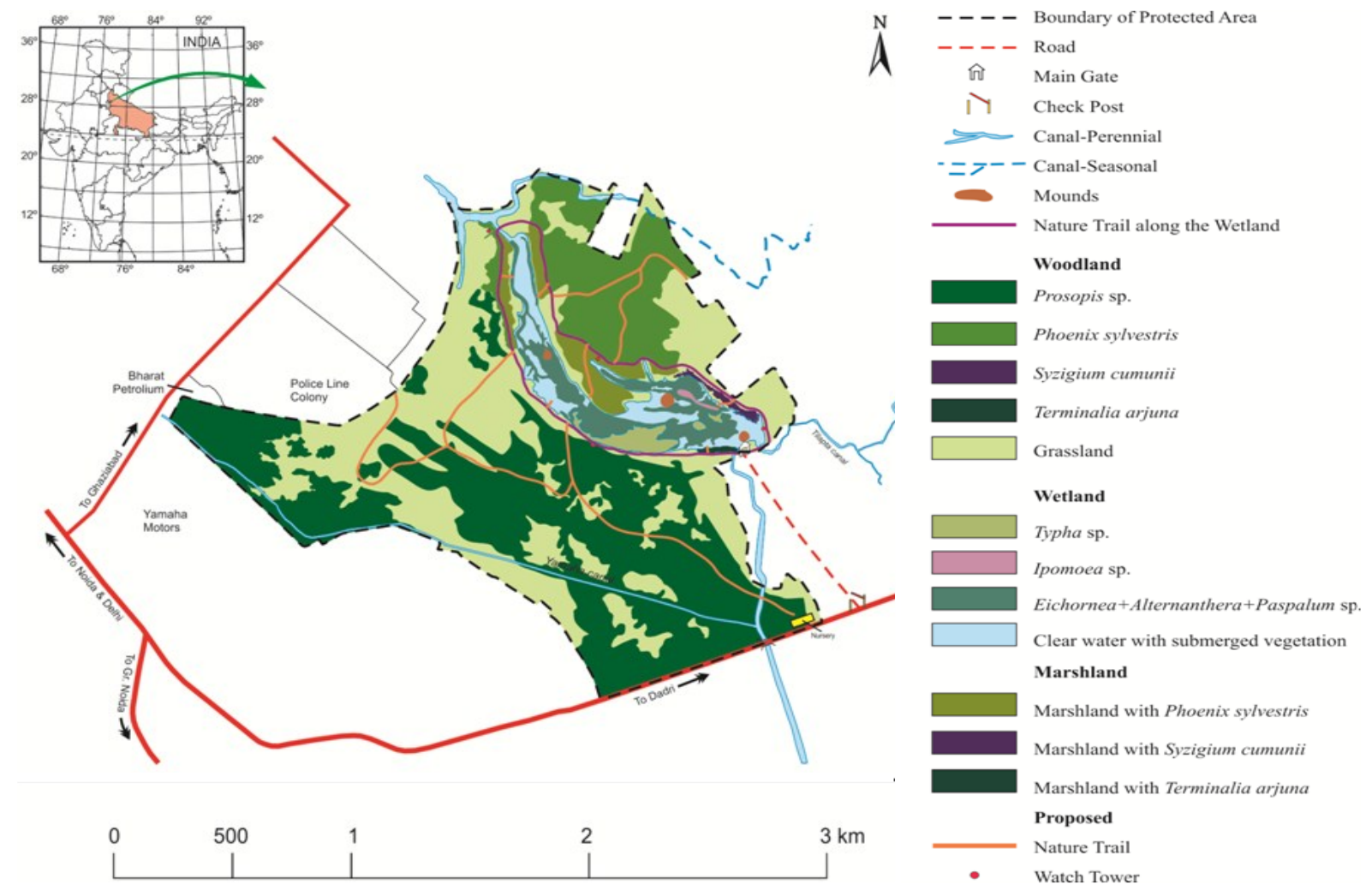

Fig. 3. Map showing micro habitats of Surajpur wetland.

Soils of Nagchoon Pond of Madhya Pradesh.

Soil Nitrogen is supposed to be the most limiting nutrient in a majority of ecosystems (Fenn et al., 1998). The values of total $\mathrm{N}$ varied significantly in different forest types (Gairola et al., 2012). $\mathrm{N}$ is the most important fertilizer element, plants respond quickly to application of nitrogen. This element encourages above ground vegetative growth and gives a deep 
green colour to the leaves helps in photosynthesis (Rai et al., 2011). In the present study, the TKN was fluctuated across the different locations in the study area and the value showed a gradual decreasing trend from TA to PJ and an overall mean of $286.76 \pm 42.41 \mathrm{mg} / \mathrm{kg}$ was recorded. Considering the critical limits of Nitrogen $(\mathrm{N})$ of $280 \mathrm{mg} / \mathrm{kg}$ (Singh et al., 1999), the results are under the permissible limits.

The biogeochemical cycle of phosphorous plays a significant role in eutrophication process (Wang et al., 2003). P is an essential element for all plants and plants will grow slowly with low levels of Phosphorus in the soil. A better supply of phosphorus has been associated with proliferous root growth resulting in enhanced water and nutrient absorption. Secondly, it is essential for laying out primordia for reproductive organs (Tisdale et al., 1985). In Surajpur wetland, the available $\mathrm{P}$ ranged between $374.24 \mathrm{mg} / \mathrm{kg}$ (TA) and $297.94 \mathrm{mg} / \mathrm{kg}$ (SC) and an overall mean of $338.50 \pm$ $32.75 \mathrm{mg} / \mathrm{kg}$ was recorded. High phosphorus content of soil represents high vegetation diversity. Similar results were reported by the researchers (Fauzie et al., 2015, Gairola et al., 2012, Mishra, 2011). An excessive concentration of $\mathrm{P}$ is the most common cause of eutrophication in freshwater lakes, reservoirs and streams (Correll, 1998).

Potassium is the third essential fertilizer element. $\mathrm{K}$ is essential for photosynthesis, for protein synthesis, for starch formation and for the translocation of sugars (Rai et al., 2011). In present study, there was not much fluctuation in $\mathrm{K}$ values across the different locations in the study area and the value ranged between 3.19 $\mathrm{mg} / \mathrm{kg}(\mathrm{PJ})$ and $2.14 \mathrm{mg} / \mathrm{kg}(\mathrm{GR})$ and an overall mean of $2.85 \pm 0.39 \mathrm{mg} / \mathrm{kg}$ was recorded. Lower $\mathrm{K}$ content was recorded because of not contamination with sewage water (Baddesha et al., 1997). Mahajan and Bellore (2014) also reported similar results of $\mathrm{K}$ values ranges between $2.50 \mathrm{mg} / 1$ to $1.10 \mathrm{mg} / \mathrm{l}$ in soil of Nagchoon Pond, Madhya Pradesh.

Calcium is a secondary macronutrient improves the soil structure thereby increasing water penetration and providing a more favourable soil environment for growth of plant roots and micro-organisms. Ca level in soil recorded an overall mean of $10.86 \pm 673 \mathrm{mg} / \mathrm{kg}$ and the value ranged between $20.75 \mathrm{mg} / \mathrm{kg}$ (PS) and $3.75 \mathrm{mg} / \mathrm{kg}$ (GR). Magnesium is a water-soluble cation and it is necessary for chlorophyll pigment in green plants (Mahajan and Billore, 2014). The Mg values were fluctuated spatially across the habitats and recorded maximum $(17.45 \mathrm{mg} / \mathrm{kg})$ in PS while minimum $(5.66 \mathrm{mg} / \mathrm{kg})$ in PJ with an overall mean of $10.56 \pm$ $4.43 \mathrm{mg} / \mathrm{kg}$ was recorded. Dense vegetation influences higher $\mathrm{Ca}$ and $\mathrm{Mg}$ level in PS and sparse vegetation reduces $\mathrm{Ca}$ and $\mathrm{Mg}$ level in GR and PJ. In Surajpur wetland, the value of calcium and magnesium resemble the general trend reported from Indian forest soils. The concentration of Iron varied from $12.53 \mathrm{mg} / \mathrm{Kg}$
(SC) to $18.08 \mathrm{mg} / \mathrm{Kg}(\mathrm{PJ})$ with an overall mean of $14.90 \pm 1.99 \mathrm{mg} / \mathrm{kg}$ was recorded and the spatial variation of $\mathrm{Fe}$ concentration was in order $\mathrm{SC}<\mathrm{TA}<\mathrm{GR}<\mathrm{PS}<\mathrm{PJ}$. Considering $6 \mathrm{mg} / \mathrm{kg}$ as the permissible limit of Fe, the soils of the study area was found to be contaminated with a slightly higher level of Fe (Patel et al., 2015).

Manganese is one of the important micro-nutrient and has a role in the formation or synthesis of chlorophyll. Due to deficiency of manganese the carbohydrate synthesis is disturbed, resulting in retarded growth, decrease in the content of ash and failure to reproduce (Singh et al., 1999). Concentration of Mn varied from $256.99 \mathrm{mg} / \mathrm{kg}$ to $373.34 \mathrm{mg} / \mathrm{kg}$ with an overall mean value of $289.13 \pm 42.89 \mathrm{mg} / \mathrm{kg}$ is good for plant growth considering the minimum of $55 \mathrm{mg} / \mathrm{kg}$ as the critical limit for Mn deficiency (Patel et al., 2015). The order of distribution along the study area is $\mathrm{TA}<\mathrm{SC}<\mathrm{PJ}<\mathrm{PS}<\mathrm{GR}$.

Zinc is an essential micronutrient regulates plant growth and it is associated with the development of chlorophyll in leaves and a high content of $\mathrm{Zn}$ is correlated with a high amount of chlorophyll. In its absence growth is less, buds fall off and seed development is limited. In small trees bronzing of leaves is mitigated by spraying zinc sulphate on leaves (Singh et al., 1999). The $\mathrm{Zn}$ concentration was not much fluctuated across the study sites and the value ranged between $3.74 \mathrm{mg} / \mathrm{kg}$ (PS) to $4.87 \mathrm{mg} / \mathrm{kg}$ (SC) with an overall mean of $4.20 \pm 0.45 \mathrm{mg} / \mathrm{kg}$. Critical limit for $\mathrm{Zn}$ deficiency in different type of soils for different crops were ranged from 0.4 to $0.8 \mathrm{mg} / \mathrm{kg}$ (Patel et al., 2015). Chloride is also important micronutrients found in the soil helps in plant metabolism and development. During the course of study, higher $\mathrm{Cl}$ content recorded and varied from $125.09 \mathrm{mg} / \mathrm{kg}$ (SC) and $308.71 \mathrm{mg} / \mathrm{kg}$ (PS) with an overall mean of $223.73 \pm 62.64 \mathrm{mg} / \mathrm{kg}$ was recorded. Sulphates are salts of sulphuric acid found naturally in soils by the decomposition of soil organic matter and essential macronutrient for the plant development and growth. It is mostly present as sulfides, sulfates and organic combinations with $\mathrm{C}$ and N. Since organic carbon and TKN recorded in higher values, sulphates also recorded in higher concentration in soul. SO4 content in the soil varied from $119.03 \mathrm{mg} / \mathrm{kg}$ to $193.65 \mathrm{mg} / \mathrm{kg}$ with an overall mean of $150.21 \pm 27.99$ $\mathrm{mg} / \mathrm{kg}$ was recorded. Spatial variation of SO4 concentration was in order $\mathrm{SC}<\mathrm{PS}<\mathrm{PJ}<\mathrm{TA}<\mathrm{GR}$. Considering the critical lowest limit of SO4 of $10 \mathrm{mg} / \mathrm{kg}$ (Patel et $a l .$, 2015), the values are good enough to enrich sulphur support to the plants.

Silica is a functional nutrient for the plants and is the second most abundant element after oxygen in soil (Mukhtar et al., 2013) and mineral substrate for plant life. When $\mathrm{Si}_{2}$ is available to plants, it plays a significant role in their growth, mineral nutrition and resistance to several stresses (Epstein, 1971). $\mathrm{SiO}_{2}$ is one 
of the micronutrient element which is proved to be useful in seed plant species mainly graminae and cyperaceae especially during environmental stress (Hattori et al., 2005). In Surajpur wetland, $\mathrm{SiO}_{2}$ concentration recorded an overall mean of $7.97 \pm 1.45 \mathrm{mg} /$ $\mathrm{kg}$ and the value showed a gradual increasing trend from TA $(6.4 \mathrm{mg} / \mathrm{kg})$ to PJ $(10.21 \mathrm{mg} / \mathrm{kg})$ and GR recorded in between these values $(7.23 \mathrm{mg} / \mathrm{kg})$.

Boron, Copper and Molybdenum are essential micronutrients and occurs in the soils in extremely small quantities, is usually found in concentrations of less than $1 \mathrm{mg} / \mathrm{kg}$ (Rudnick and Gao, 2003). However the small amounts of boron helps in use of nutrients and regulates other nutrients, copper is important in reproductive growth and molybdenum helps the plants in $\mathrm{N}$ metabolism. B, $\mathrm{Cu}$ and Mo nutrients recorded less than one $\mathrm{mg} / \mathrm{kg}$ in the soil sample of Surajpur wetland and similar results were reported by Patel et al. (2015) in soils of central India.

Sodium have a ubiquitous presence in soils and waters and are widely taken up and utilized by plants, but are not considered as plant nutrients because they do not meet the strict definition of "essentiality." $\mathrm{Na}$ has a very specific function in the concentration of carbon dioxide in a limited number of $\mathrm{C} 4$ plants and thus is essential to these plants called 'functional nutrient'. The amount of $\mathrm{Na}$ required in very small quantity to the plants but is an essential element for animals (Subbarao et al., 2003), and in the present study, Na detected an overall mean of $2.38 \pm 1.18 \mathrm{mg} / \mathrm{kg}$. Mahajan and Bellore, (2014) also recorded similar results of $\mathrm{Na}$ ranges between 1.80 to $1.10 \mathrm{mg} / \mathrm{kg}$ in soils of Nagchoon Pond, Madhya Pradesh.

Bacteria and fungi, the major types of microorganisms found in soil, play an essential role in nutrient transformations (Popeláŕová et al., 2008). The most numerous microbes in soil are bacteria and are universally present in all types of substances water, food, soil, vegetation and air. The viable count of bacteria (TPC) shows a gradual increasing trend from TA to GR and recorded maximum $(32,00,000 \mathrm{cfu} / \mathrm{g})$ in $\mathrm{GR}$ and minimum $(68,00,00 \mathrm{cfu} / \mathrm{g})$ in TA with an overall mean of $16,56,000.00 \pm 11,06,157.31 \mathrm{cfu} / \mathrm{g}$. The results are in agreement to other similar study of Ogunmwony et al., (2008), wherein the mean total bacterial counts (TBC) of soil sample ranged from $9.5 \times 10^{7} \mathrm{cfu} / \mathrm{g}$ to $8.0 \times 10^{5}$ $\mathrm{cfu} / \mathrm{g}$ in soils of Nigeria.

\section{Conclusion}

The result described above indicated that the essential mineral nutrients are widely distributed and are mostly within the normal range of soil. Due to the dry and arid conditions of the soil of the Surajpur, $\mathrm{pH}$, available $\mathrm{P}$ and organic matters recorded slightly enhanced level. Other parameters are under the permissible limits because the soil is pollution free and no any organic waste is coming to the site. Nutrient levels are high in wetland habitat as wetlands have rich biomes and support high levels of biodiversity. It was concluded that the soil is good enough to support rich biodiversity to form a complete food web in the Surajpur wetland ecosystem.

\section{ACKNOWLEDGEMENTS}

I would like to express my sincere gratitude to World Wide Fund for Nature-India for providing support and guidance to conduct this study. I would like to thank Uttar Pradesh Forest Department for permission to perform the study.

\section{REFERENCES}

APHA (2001). Standard methods for the examination of water and wastewater. $20^{\text {th }}$ ed., American Public Health Association, Washington, DC.

APHA (2006). Standard methods for the examination of water and wastewater, $22^{\text {nd }}$ ed., American Public Health Association, Washington, DC.

Baddesha, H.S., Chhabra, R. and Ghuman, B.S. (1997). Changes in soil chemical properties and plant nutrient content under eucalyptus irrigated with sewage water. Journal of Ind. Soc. of Soil Science, 45(2): 358-362

Bahuguna, Y.M., Gairola, S., Semwal, D.P., Uniyal, P.L. and Bhatt, A.B. (2012). Soil physico-chemical characteristics of bryophytic vegetation residing Kedarnath Wildlife Sanctuary (KWLS), Garhwal Himalaya, Uttarakhand, India. Indian Journal of Science and Technology, 5(4): 2547-2553

Balling, R.C, Klopatek, J.M., Hildebrandt, M.L., Moritz, C. and Watts, C.J. (1998). Impacts of land degradation on historical temperature records from the Sonoran desert. Climatic Change, 40: 669-681

Bhattacharyya, T., Pal, D.K., Mandal, C., Chandran, P., Ray, S.K., Sarkar, D., Velmourougane, K., Srivastava, A., Sidhu, G.S., Singh, R.S., Sahoo, A.K., Dutta, D., Nair, K.M., Srivastava, R., Tiwary, P., Nagar, A.P. and Nimkhedkar, S.S. (2013). Soils of India: historical perspective, classification and recent advances. Current Science, 104(10): 1308-1323

Bura, P., Ansari, N.A. and Nawab, A. (2013). Ecological Assessment, Conservation and Management of Surajpur Wetland, Greater Noida, Uttar Pradesh. In: P. Kumar, P. Singh, R.J. Srivastava (Ed.) Proceeding of International Conference on Water and Biodiversity, Uttar Pradesh State Biodiversity Board, Lucknow, Uttar Pradesh, pp: 95-103

Castelle, A.J., Johnson, A.W. and Conolly, C. (1994). Wetland and stream buffer size requirements: A review. Journal of Environmental Quality, 23(5): 878-882

Chaudhari, P.R., Ahire, D.V., Ahire, V.D., Chkravarty, M. and Maity, S. (2013). Soil Bulk Density as related to Soil Texture, Organic Matter Content and available total Nutrients of Coimbatore Soil. Int. J. of Scientific and Res. Pub., 3(2): 1-8

Correlli, D.L. (1998). The role of phosphorus in the eutrophication of receiving waters: A Review. J. Environ. Qual., 27: 261-266

Doran, J.W. and Parkin, T.B. (1994). Defining and assessing soil quality. In: J.W. Doran et al. (eds.) Defining Soil Quality for a Sustainable Environment. Soil Science 
Society of America, Madison, WI, Special Publication 35, pp. 3-22

Epstein, E. (1971). Mineral nutrition of plants. Principles and Perspectives. John Wiley and Sons Inc., New York, London, Sydney, Toronto.

Fauzie, A.K., Khudsar, F.A. and Sreenivasa. (2015). Analysis of soil physico-chemical properties in various sites at yamuna biodiversity park, Delhi, India. Int. J. of Innovative Res. in Science, Eng. and Tech., 4(8): 7220-7228

Fenn, M.E., Poth, M.A., Aber, J.D., Boron, J.S., Bormann, B.J., Johnson, D.W., Lenly, A.D., McNulty, S.G., Ryan, D.F., Stottlemeyer, R. (1998). Nitrogen excess in North American ecosystems: predisposing factors, ecosystem responses and management strategies. Ecol. Appl., 8(3): 706-733

Gairola, S., Sharma, C.M., Ghildiyal, S.K. and Suyal, S. (2012). Chemical properties of soils in relation to forest composition in moist temperate valley slopes of Garhwal Himalaya, India. Environmentalist, 32(4): 512523

Gowd, S.S., Reddy, M.R. and Govila, P.K. (2010). Assessment of heavy metal contamination in soils at Jajmau (Kanpur) and Unnao industrial areas of the Ganga Plain, Uttar Pradesh, India. Journal of Hazardous Materials, 174: $113-121$

Gupta, P.K. (2004). Methods in environmental analysiswater, Soil and Air. Agrobios, Jodhpur, India.

Hattori, T., Inanaga, S., Araki, H., Morita, AnP., Luxova, M. and Alexander M. (2005). Application of Silicon enhanced drought tolerance in Sorghum bicolor. Physiologia Plantarum, 123(4): 459-466

ISO (2001). Soil quality- Dissolution for the determination of total element content- Part 1: Dissolution with hydrofluoric and perchloric acids, International Standard Organization 14869-1:2 001. 1-5p.

Joshi, B.C. (2009). District Brochure of Gautam Budh Nagar, Uttar Pradesh, India. $22 \mathrm{p}$.

Karthick, B. and Ramachandran, T.V. (2006). Water quality status of sharavathi river basin, Western Ghats, ENVIS Technical Report: 23, Energy and Wetlands Research Group, Centre for Ecological Sciences, Indian Institute of Science, Bangalore.

Kissel, D.E. and Sonon, L. (Eds.). (2008). Soil test handbook for Georgia. Special Bulletin. Georgia Cooperative Extension, College of Agricultural and Environmental Sciences. The University of Georgia Athens, Georgia. 99p.

Lungmuana, and Colney, L. (2011). Soil testing - an important tool for assessing soil health and quality. Science Vision, 11(4): 214-217

Mahajan, S. and Billore, D. (2014). Assessment of physicochemical characteristics of the soil of Nagchoon Pond Khandwa, Madhya Pradesh, India. Res. J. Chem. Sci., 4 (1): 26-30

Manral, U., Raha, A., Solanki, R., Hussain, S.A., Babu, M.M., Mohan, D., Veeraswami, G.G., Sivakumar, K. and Talukdar, G. (2013). Plant species of Okhla Bird Sanctuary: A wetland of Upper Gangetic Plains, India. Check List, 9(2): 263-274

Mendhe, K. (1997). Studies of hydro chemical characters and phytoplankton population of Bilawali Talab Indore, Ph.D. Thesis D.A.V.V. Indore, Madhya Pradesh.

Mishra, B.P. (2011). Vegetation composition and soil nutri- ents status from polyculture to monoculture. African Journal of Environmental Science and Technology, 5 (5): $363-366$

Mitsch, W.J. and Gosselink, J.G. (1989). Wetlands, Van Nostrand Reinhold Company, New York: 14-18

Morisada, K., Ono, K. and Kanomata, H. (2004). Organic carbon stock in forest soils in Japan. Geoderma, 119: 21 $-32$

Mukhtar, A., Kamran, A., Muhammad, A., Ummara, Q., Zammurad, I.A. and Goyal, A. (2013). Silicon priming: a potential source to impart abiotic stress tolerance in wheat: A review. Australian Journal of Conservation Science, 7(4): 484-491

Ogunmwonyi, I.N., Igbinosa, O.E., Aiyegoro, O.A., and Odjadjare, E.E. (2008). Microbial analysis of different top soil samples of selected site in Obafemi Awolowo University, Nigeria. Scientific Research and Essay, 3 (3): $120-124$

Patel, K.S., Chikhlekar, S., Ramteke, S., Sahu, B.L., Dahariya, N.S. and Sharma, R. (2015). Micronutrient Status in Soil of Central India. American Journal of Plant Sciences, 6: 3025-3037

Pilania, P.K. and Panchal, N.S. (2014). Soil and Plant Relation at Little Rann of Kutch of Gujarat in Western India. International Journal of Advanced Research, 2(7): 1-10

Popelářová, E., Voříšek, K., Strnadová, S. (2008). Relations between activities and counts of soil microorganisms. Plant, Soil and Environment, 54(4): 163-170

Rai, S., Chopra, A.K., Pathak, C., Sharma, D.K., Sharma, R. and Gupta, P.M. (2011). Comparative study of some physicochemical parameters of soil irrigated with sewage water and canal water of Dehradun city, India. Archives of Applied Science Research, Scholars Research Library, 3(2): 318-325

Raina, A.K. and Gupta, M.K. (2009). Soil and vegetation studies in relation to parent material of Garhwal Himalayas, Uttarakhand (India). Annals of Forestry, 17(1): $71-82$

Ramachandra, T.V. (2001). Restoration and management strategies of wetlands in developing countries. Electronic Green Journal, 15: 1-16

Ray, S.K., Bhattacharyya, T., Reddy, K.R., Pal, D.K., Chandran, P., Tiwary, P., Mandal, D.K. et. al. (2014). Soil and land quality indicators of the Indo-Gangetic Plains of India. Current Science, 107(9): 1470-1486

Rodgers, W.A., Panwar, H.S. and Mathur, V.B. (2002). Wildlife Protected Area Network in India: A Review (Executive Summary). Wildlife Institute of India, Dehradun. $44 \mathrm{p}$.

Rudnick, R.L. and Gao, S. (2003). The Composition of the Continental Crust. In: Holland, H.D. and Turekian, K.K., Eds., Treatise on Geochemistry, Vol. 3, The Crust, Elsevier-Pergamon, Oxford, 1-64.

Shrivastava, A. (1996). Studies on the macrophytic vegetation of Pipalyapala talab, Indore, Ph.D. Thesis, D.A.V.V. Indore, Madhya Pradesh, India.

Singh, D., Chhonkar, P.K. and Pandey, R.N. (1999). Soil, plant \& water analysis - A method manual. Indian Agricultural Research Institute, New Delhi.

Singh, S.P., Ram, J., Walia, C.S., Sachdev, C.B., Dhankar, R.P., Rana, K.P.C., Sehgal, J., Velayutham, M. and Gajbhiye, K.S. (2004). Soils of Uttar Pradesh: their kinds, distribution, characterization and interpretation 
for optimising Land Use. National Bureau of Soil Survey and Land Use Planning in collaboration with Department of Agriculture, Government of Uttar Pradesh $112 p$.

Srivastava, A. and Yadav, S. (2014). Edaphological Study of Bundelkhand (India). Int. J. of Bio. Pharmacy and Allied Sciences, 3(10): 2223-2228

Subbarao, G.V., Ito, O., Berry, W.L. and Wheeler, R.M. (2003). Sodium- A Functional Plant Nutrient. Critical Reviews in Plant Sciences, 22(5): 391-416.

Swaminathan, M.S. (2005). International conference on Soil, Water and Environmental Quality-Issues and Strategies, New Delhi, India, Jan 29- Feb 01, 2005, organized byIndian Society of Soil Science.

Tisdale, S.L., Nelson, W.L. and Beaton, J.D. (1985). Soil Fertility and Fertilizers. Macmillan Publishing Company, New York (USA).

Tiwari, D.D., Katiyar, N.K. and Pandey, S.B. (2014). Appraisal of available sulphur and micronutrient status in southwest plain zone soils of Agra, Uttar Pradesh. Crop Res., 48 (1,2\&3): 80-83
USEPA, (1996). Soil screening guidance: technical background document. United States Environmental Protection Agency Report 540/R-95/128. US Gov. Print Office, Washington DC.

Wang, H., Appan, A., John, S. and Gulliver. (2003). Modelling phosphorous dynamics in aquatic sediments, 1model development. Water Research, 37: 3928-3938.

Whitney, M. and Means, T.H. (1897). An electrical method of determining the soluble salt content of soils. USDA, Division Soils Bull no. 8. U.S. Gov. Print. Office, Washington. DC.

Yadav, A. and Shukla, D.N. (2015). Assessment of heavy metal accumulation in wastewater flooded soil of Allahabad, Uttar Pradesh, India. Int J Res Rev., 2(6): 324-329

Yadav, A., Yadav, P.K. and Shukla, D.N. (2013). Investigation of heavy metal status in soil and vegetables grown in urban area of Allahabad, Uttar Pradesh, India. International Journal of Scientific and Research Publications, 3(9): 1-7 